\title{
Killing of Yeast, Germ-tube and Mycelial Forms of Candida albicans by Murine Effectors as Measured by a Radiolabel Release Microassay
}

\author{
By MANUELA BACCARINI, ${ }^{1}$ ANNA VECCHIARELLI, ${ }^{1}$ \\ ANTONIO CASSONE ${ }^{2 *}$ AND FRANCESCO BISTONI ${ }^{1}$ \\ ${ }^{1}$ Institute of Medical Microbiology, University of Perugia, Perugia, Italy \\ 2 Laboratory of Bacteriology and Medical Mycology, Istituto Superiore di Sanità, Rome, Italy
}

(Received 9 July 1984)

\begin{abstract}
Candida albicans undergoes yeast to mycelial conversion under both in vivo and in vitro conditions but the relative pathogenicity of the two forms of growth is still unknown. By adapting a recently developed ${ }^{51} \mathrm{Cr}$ radiolabel release assay, we have quantified the killing ability of different murine effector cell populations for the hyphal form of C. albicans. Up to $50 \%$ of specific ${ }^{51} \mathrm{Cr}$ release from the mycelial form could be detected after incubation for only $1 \mathrm{~h}$, with no requirement for opsonization, provided that appropriate effector : target cell ratios were used. The specific ${ }^{51} \mathrm{Cr}$ release correlated well with viability, as assessed by dye exclusion tests, and with pathogenicity potential in cyclophosphamide-immunodepressed mice. Comparison of the activity of different murine effectors against yeast and hyphal forms showed that hyphal forms were killed by murine effectors to a similar, if not greater, extent than yeast forms. In particular, thioglycollate-induced murine polymorphonuclear neutrophils were able to kill hyphal cells extracellularly and without an opsonic requirement.
\end{abstract}

\section{INTRODUCTION}

We have recently described a radiolabel release microassay to quantify killing of ${ }^{51} \mathrm{Cr}$-labelled Candida albicans yeasts by different murine effector cell populations in both normal and immunomodulated hosts (Bistoni et al., 1982; Baccarini et al., 1983a,b). However, C. albicans undergoes a dimorphic transition (yeast-form to hyphal-form cells) under in vivo and in vitro conditions (Odds, 1979; Dabrowa et al., 1976; Shepherd et al., 1980; Simonetti et al., 1974; Mattia et al., 1982). This transition is important in the expression of fungal pathogenicity, although no definitive evidence has been provided on the relative pathogenicity of the different forms of growth. It has been suggested that hyphal forms are endowed with in vivo resistance to host phagocytic defences via a variety of mechanisms (Saltarelli et al., 1975; Davies \& Dennings, 1972). In the present study we investigated this presumed role of hyphal forms of $C$. albicans by developing a suitable modification of the short-term radiolabel release assay reported previously (Bistoni et al., 1982). Using this assay, we have compared killing of the two different forms of growth of $C$. albicans by murine effector cells in vitro. After this paper had been submitted Cockayne \& Odds (1984) reported phagocytosis and intracellular killing of different morphological forms of $C$. albicans by human polymorphonuclear leucocytes, using a different procedure.

\section{METHODS}

Organism and growth. The strain of Candida albicans used throughout this study was isolated from a clinical specimen and identified according to established taxonomic criteria (Lodder, 1970; Marconi et al., 1976). The yeast was grown to stationary phase at $28^{\circ} \mathrm{C}$, under slight agitation, in low-glucose Winge medium composed of

Abhreriations: BM, bone marrow cells; PEC, peritoneal exudate cells; PMN, polymorphonuclear neutrophils; $\mathrm{SC}$, spleen cells, GlcNAc, $N$-acetyl-D-glucosamine. 
$0.2 \%$ glucose and $0.3 \%$ yeast extract (BBL). Under these conditions, the culture yielded approximately $2.8 \times 10^{8}$ cells $\mathrm{ml}^{-1}$ and the organism grew as an essentially pure yeast-phase population (Mattia \& Cassone, 1979). Cells were harvested by low speed centrifugation, washed twice in saline and diluted to the desired concentration.

Germ-tube and hyphal formation. Yeast cells grown to stationary phase were harvested from Winge medium, washed twice in saline and then resuspended to a final concentration of $10^{7}$ cells $\mathrm{ml}^{-1}$ in basal saline medium: $\left(\mathrm{NH}_{4}\right)_{2} \mathrm{SO}_{4}, 0.5 \% ; \mathrm{Mg}_{2} \mathrm{SO}_{4} .7 \mathrm{H}_{2} \mathrm{O}, 0.02 \% ; \mathrm{NaCl}, 0.5 \%$; biotin, $0.001 \%$; and $\mathrm{N}$-acetyl-D-glucosamine (GlcNAc), $4 \mathrm{~mm}$. Cells were incubated at $37^{\circ} \mathrm{C}$ under slight agitation, and germ-tube formation was evaluated under a light microscope. Using this induction with GlcNAc more than $90 \%$ of the yeast cells developed first as germ-tubes $(90$ $120 \mathrm{~min}$ ), then as hyphae with a septum after $240-270 \mathrm{~min}$ of induction at $37^{\circ} \mathrm{C}$. At different stages of yeastmycelial conversion, $100 \mathrm{ml}$ of the suspension (approx. $10^{9}$ cells) were filtered on $0.8 \mu \mathrm{m}$ membrane filters (type AA, $47 \mathrm{~mm}$; Millipore), harvested and further processed as described below.

Preparation of effector cells. Two- to four-month-old hybrid (BALB/c Cr $\times \mathrm{DBA} / 2 \mathrm{Cr}$ ) F1 mice (CD2F1) of both sexes were obtained from Charles River Labs, Calco, Italy, and from our colony. Spleen cells (SC) were obtained by standard techniques. Peritoneal exudate cells (PEC) were induced by intraperitoneal injection of $1 \mathrm{ml}$ of $10 \%$ thioglycollate broth (Bacto-Brewer thioglycollate medium; Difco) $4 \mathrm{~d}$ before testing and were collected by washing out the peritoneal cavity with $10 \mathrm{ml}$ RPMI medium. Peritoneal polymorphonuclear neutrophils (PMN) were obtained from the peritoneal cavity of mice $18 \mathrm{~h}$ after the intraperitoneal injection of $1 \mathrm{ml}$ of $10 \%$ thioglycollate broth; the elicited cells were harvested by peritoneal washing and approximately $85 \%$ were found to be PMN by morphological criteria. To collect bone marrow (BM) cells, the femur was isolated and removed intact from the hind limb. After clearing from the adherent muscle, the bone was cut at both ends in the region of metaphysis. The bone marrow was flushed from the shaft from the proximal side with $1 \mathrm{mI}$ RPMI medium, and dispersed by a repeated gentie aspiration with a syringe (Gould et al., 1975).

Reagents. $N$-Acetylglucosamine and biotin were obtained from Sigma. RPMI 1640 medium which was used throughout this study, and foetal and newborn calf sera were obtained from Eurobio Labs, Paris, France. Cyclophosphamide, from Endoxan Asta, Asta Werke, FRG, was injected into mice intraperitoneally in a volume of $0.1 \mathrm{ml}$ per $10 \mathrm{~g}$ body weight. Murine hyperimmune serum (agglutination titre 1/512) was obtained from mice given four injections each of $2 \times 10^{7}$ merthiolate-inactivated $C$. albicans organisms (at $60,45,30$ and $15 \mathrm{~d}$ before bleeding) by subcutaneous and intraperitoneal routes. Normal murine serum was obtained from healthy CD2F1 mice.

In vitro assay against yeast-form $C$. albicans. The microassay against yeast-form $C$. albicans has been described previously (Bistoni et al., 1982). Briefly, various numbers of different effector cells in 0.1 ml RPMI medium were mixed in U-shaped microtitre plates (Greiner Labortechnik, Nürtingen, FRG) with $5 \times 10^{4}$ radiolabelled [ $300 \mu \mathrm{Ci}(111 \mathrm{MBq}) \mathrm{Na}_{2} \mathrm{CrO}_{4}$ for $2 \mathrm{~h}$ at $37^{\circ} \mathrm{C}$ in $5 \% \mathrm{CO}_{2}$ ] C. albicans yeasts. After incubation for $4 \mathrm{~h}$ at $37^{\circ} \mathrm{C}$ in $5 \% \mathrm{CO}_{2}$, the plates were centrifuged at $800 \mathrm{~g}$ for $10 \mathrm{~min}$, and the radioactivity in $0.1 \mathrm{ml}$ of the supernatant was measured in a $\gamma$-scintillation counter (Autogamma 500C, Packard Instruments). Results were expressed as the percentage release in the experimental group (quadruplicate samples) above the baseline control (C. albicans incubated alone in RPMI medium) according to the following formula:

$$
\text { Percentage specific release }=\frac{\text { c.p.m. experimental group }- \text { c.p.m. spontaneous release }}{\text { Total c.p.m./2 }} \times 100
$$

where total c.p.m. is the radioactivity incorporated by $5 \times 10^{4} \mathrm{C}$. albicans cells. The same technique was used to assess the killing of $C$. albicans after $30 \mathrm{~min}$ of induction of germ-tube formation.

In vitro assay against C. albicans hyphae. (a) Chromium labelling of hyphal-form C. albicans. A $100 \mathrm{ml}$ sample of suspension containing $2 \times 10^{8} \mathrm{C}$. albicans germ-tubes or hyphae was filtered on $0.8 \mu \mathrm{m}$ membrane filters. The cells were harvested by scraping the filters with a razor blade and then mixed with $300 \mu \mathrm{Ci} \mathrm{Na}{ }_{2}^{51} \mathrm{CrO}_{2}$ ( $\mathrm{New}$ England Nuclear). After $2 \mathrm{~h}$ incubation at $37{ }^{\circ} \mathrm{C}$ in $5 \% \mathrm{CO}_{2}$, the micro-organisms were resuspended in $50 \mathrm{ml}$ basal saline medium, filtered on a $0.8 \mu \mathrm{m}$ membrane filter, and the filter was washed twice with $100 \mathrm{ml}$ basal saline medium. The micro-organisms were then resuspended in RPMI medium to a concentration of $5 \times 10^{5}$ cells ml $\mathrm{m}^{-1}$. Under standard labelling conditions, $5 \times 10^{4}$ C. albicans germ-tubes gave about $1500 \pm 500$ c.p.m. while $5 \times 10^{4}$ hyphae gave $2500 \pm 500$ c.p.m.

(b) Assay procedure. Various numbers of effector cells $(0.1 \mathrm{ml})$ were mixed in flat-bottomed 96-well microtitre plates with $5 \times 10^{+}$C. albicans germ-tubes or hyphae $(0.1 \mathrm{ml})$. After $1 \mathrm{~h}$ incubation (unless otherwise stated) at $37{ }^{\circ} \mathrm{C}$ in $5 \% \mathrm{CO}_{2}$, the cell-micro-organism mixture was harvested by a multiple section filtration apparatus (Mash II, Microbiological Association, Bethesda, Md, USA) by means of a fibreglass filter paper (grade $934 \mathrm{AH}$; Reeve Angel Co., Clifton, NJ, USA). Radioactivity of paper discs containing the radiolabelled organisms was measured in a $\gamma$-scintillation counter. Target cells incubated without effector cells always retained more than $90 \%$ of the total radioactivity incorporated and served as baseline release. Results of experimental groups were expressed as the percentage specific ${ }^{51} \mathrm{Cr}$ release according to the following formula:

$$
\text { Percentage specific release }=\frac{\text { c.p.m. baseline release }- \text { c.p.m. experimental group }}{\text { Total c.p.m. incorporated }} \times 100
$$


Standard errors were usually below $2 \cdot 5 \%$. The same technique was used to determine the killing of germ-tubes after $90 \mathrm{~min}$ induction. In some control experiments yeasts incubated for 0 or $30 \mathrm{~min}$ in basal saline medium gave similar results with this assay technique and the previous one (see above).

Determination of dry weight. For dry weight determinations, the organisms were harvested and filtered on pretared $0.8 \mu \mathrm{m}$ membrane filters. Filters were washed with $50 \mathrm{ml}$ distilled water, dried in an oven at $80^{\circ} \mathrm{C}$ for $12 \mathrm{~h}$, and weighed.

Statistical analysis. For the in vivo experiments, differences in the median survival times were analysed according to the Mann-Whitney U-test. Experimental groups consisted of 10 animals each.

\section{RESULTS}

Killing of yeast and hyphal forms of $C$. albicans at different effector : target ratios

In preliminary experiments, we investigated the effect of varying the effector : target ratios on ${ }^{51} \mathrm{Cr}$ release from yeast or hyphal forms of $C$. albicans. Effector cells known to display different levels of reactivity against yeast-form $C$. albicans were used, viz. PMN, which exert a strong candidacidal activity, and SC, which kill the yeast to a much lesser extent. All the effector cell populations were able to kill the hyphal form ( 240 min development in GlcNAc medium) at levels comparable to or even higher than those against the yeast form (Table 1). In this table, the ratios are also expressed as number of effector cells : dry weight of the target. These ratios are significantly lower for the hyphal form with respect to the yeast form, since they take into account the increase of the dry mass of target cell during the mycelial conversion (about $40 \%$ ). The optimal effector : target cell ratios were in the range $10: 1$ to $5: 1$ for both types of effector cell tested.

In selected experiments, the ability of PMN and SC to ingest yeast $(0 \mathrm{~min})$ and hyphal $(240 \mathrm{~min}$ ) forms of $C$. albicans was microscopically assessed after $60 \mathrm{~min}$ of effector-target contact. Hyphal cell viability was also determined by trypan blue exclusion. The results of these experiments showed that yeast forms were ingested efficiently by PMN, and less so by SC, whereas neither PMN nor SC were able to engulf completely a significant number of hyphal forms. PMN-ingested yeasts only occasionally produced germ-tube outgrowth since most of

\section{Table 1. Effect of different effector:target ratios on the killing of C. albicans yeasts and hyphae} by different murine effectors

The effector : target ratios are expressed either as number of effector cells : target cells or as number of effector cells : target cell dry wt. The dry weight of the target is expressed as $1 \mu \mathrm{g}$ (corresponding to about $1.5 \times 10^{5}$ cells). ${ }^{51} \mathrm{Cr}$-labelled yeasts were incubated with effector cells for $4 \mathrm{~h} ;{ }^{51} \mathrm{Cr}$-labelled hyphae were incubated with effector cells for $1 \mathrm{~h}$. Standard errors, always below $2 \%$, have been omitted.

\begin{tabular}{|c|c|c|c|c|}
\hline \multirow[b]{2}{*}{$\begin{array}{l}\text { Target } \\
\text { cell }\end{array}$} & \multirow[b]{2}{*}{$\begin{array}{l}\text { Effector cell : target } \\
\text { cell ratio }\end{array}$} & \multirow[b]{2}{*}{$\begin{array}{l}\text { Effector cell : target } \\
\text { cell dry wt ratio }\end{array}$} & \multicolumn{2}{|c|}{$\begin{array}{c}\text { Percentage specific } \\
{ }^{51} \mathrm{Cr} \text { release in the } \\
\text { presence of*: }\end{array}$} \\
\hline & & & SC & PMN \\
\hline \multirow[t]{7}{*}{ Yeast } & $40: 1$ & $12: 1$ & $4 \cdot 27$ & $19 \cdot 0$ \\
\hline & $20: 1$ & $6: 1$ & $8 \cdot 72$ & $26 \cdot 6$ \\
\hline & $10: 1$ & $3: 1$ & $16 \cdot 6$ & $25 \cdot 9$ \\
\hline & $5: 1$ & $1 \cdot 5: 1$ & $14 \cdot 4$ & $21 \cdot 4$ \\
\hline & $2 \cdot 5: 1$ & $0 \cdot 75: 1$ & $10 \cdot 5$ & $17 \cdot 3$ \\
\hline & $1 \cdot 25: 1$ & $0.375: 1$ & $5 \cdot 52$ & 12.9 \\
\hline & $0.625: 1$ & $0 \cdot 188: 1$ & 0.94 & $12 \cdot 8$ \\
\hline \multirow[t]{7}{*}{ Hyphal } & $40: 1$ & $9 \cdot 8: 1$ & $20 \cdot 2$ & $38 \cdot 5$ \\
\hline & $20: 1$ & $4 \cdot 6: 1$ & $19 \cdot 6$ & $50 \cdot 0$ \\
\hline & $10: 1$ & $2 \cdot 3: 1$ & 31.9 & $56 \cdot 9$ \\
\hline & $5: 1$ & $1 \cdot 15: 1$ & $26 \cdot 5$ & $37 \cdot 4$ \\
\hline & $2 \cdot 5: 1$ & $0 \cdot 575: 1$ & $15 \cdot 6$ & $37 \cdot 7$ \\
\hline & $1 \cdot 25: 1$ & $0 \cdot 288: 1$ & 8.05 & $31 \cdot 7$ \\
\hline & $0.625: 1$ & $0 \cdot 144: 1$ & $0 \cdot 30$ & $21 \cdot 4$ \\
\hline
\end{tabular}

* Effector cells used in the assay: SC, spleen cells; PMN, polymorphonuclear cells. 


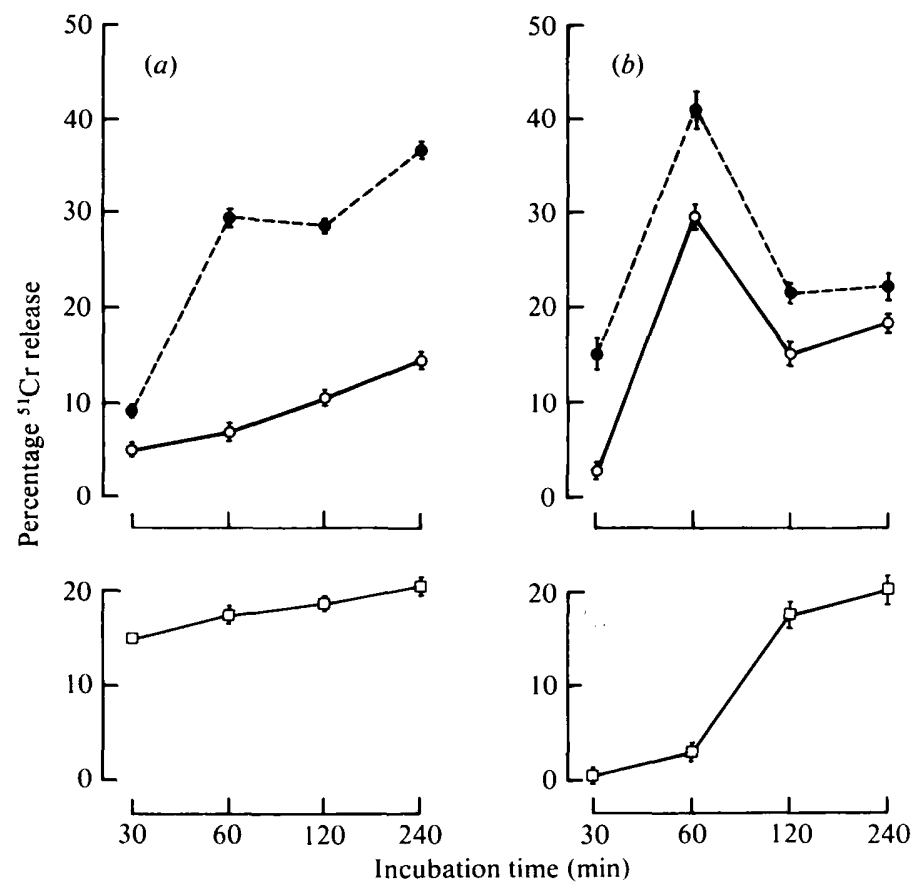

Fig. 1. Time course of specific (top panels) or spontaneous (lower panels) release of ${ }^{51} \mathrm{Cr}$ from yeastform $(a)$ and hyphal-form $(b) C$. albicans in the presence of murine effectors. $\square$, Target cells incubated in RPMI medium; 0 , target cells incubated with PMN; O, target cells incubated with SC. The effector:target ratio was $10: 1$. Vertical bars represent SEM.

Table 2. Effect of serum addition on the killing of yeast and hyphal forms of C. albicans by murine SC and PMN

\begin{tabular}{|c|c|c|c|c|c|c|c|}
\hline \multirow[b]{2}{*}{$\begin{array}{l}\text { Target } \\
\text { cell* }\end{array}$} & \multirow[b]{2}{*}{$\begin{array}{l}\text { Effector } \\
\text { cell }\end{array}$} & \multicolumn{6}{|c|}{ Percentage specific ${ }^{51} \mathrm{Cr}$ release in the presenc of $\dagger$ : } \\
\hline & & $\begin{array}{l}\text { No } \\
\text { serum }\end{array}$ & $\begin{array}{l}\text { NBS } \\
(10 \%)\end{array}$ & $\begin{array}{c}\text { HINBS } \\
(10 \%)\end{array}$ & $\begin{array}{l}\text { FCS } \\
(10 \%)\end{array}$ & $\begin{array}{l}\text { Autologous } \\
\text { serum }(5 \%)\end{array}$ & $\begin{array}{l}\text { Hyperimmune } \\
\text { serum }(5 \%)\end{array}$ \\
\hline Yeast & $\begin{array}{l}\text { PMN } \\
\text { SC }\end{array}$ & $\begin{array}{l}24 \cdot 8 \\
10 \cdot 8\end{array}$ & $\begin{array}{l}25 \cdot 7 \\
14 \cdot 2\end{array}$ & $\begin{array}{l}28 \cdot 2 \\
21 \cdot 0\end{array}$ & $\begin{array}{l}30 \cdot 6 \\
21 \cdot 0\end{array}$ & $\begin{array}{l}32 \cdot 7 \\
18 \cdot 6\end{array}$ & $\begin{array}{l}28 \cdot 6 \\
16 \cdot 1\end{array}$ \\
\hline Hyphal & $\begin{array}{l}\text { PMN } \\
\text { SC }\end{array}$ & $\begin{array}{l}49 \cdot 8 \\
27 \cdot 1\end{array}$ & $\begin{array}{l}43 \cdot 0 \\
23 \cdot 5\end{array}$ & $\begin{array}{l}39 \cdot 2 \\
23 \cdot 4\end{array}$ & $\begin{array}{l}38 \cdot 5 \\
15 \cdot 4\end{array}$ & $\begin{array}{l}36 \cdot 5 \\
18 \cdot 6\end{array}$ & $\begin{array}{l}33 \cdot 2 \\
15 \cdot 0\end{array}$ \\
\hline
\end{tabular}

* When target cells were ${ }^{51} \mathrm{Cr}$-labelled yeasts, the release assay was done for $4 \mathrm{~h}$; when ${ }^{51} \mathrm{Cr}$-labelled hyphae were used, the release assay was done for $1 \mathrm{~h}$.

+ Percentage specific ${ }^{51} \mathrm{Cr}$ release at the effector:target ratio of $10: 1$; standard errors were always below $2 \%$, and therefore have been omitted. NBS, newborn serum; HINBS, heat-inactivated newborn serum; FCS, foetal calf serum.

them were killed in less than $1 \mathrm{~h}$ (see also Bistoni et al., 1982). Despite the low ingestion efficiency, PMN were mostly able to kill the hyphal form by an extracellular non-phagocytic mechanism after adhesion to a portion of the hyphal wall. Dye exclusion experiments showed that $55-70 \%$ of the PMN-attached hyphal forms were killed in about $1 \mathrm{~h}$. Analogous experiments indicated that no more than $20 \%$ of hyphal forms were killed extracellularly by SC.

Time course of ${ }^{51} \mathrm{Cr}$ release from yeast-and hyphal-form C. albicans

The effect of varying the incubation periods on ${ }^{51} \mathrm{Cr}$ release from yeast- and hyphal-form $C$. albicans is shown in Fig. $1 .{ }^{51} \mathrm{Cr}$ release from yeast cells (Fig. 1 a) increased regularly from $30 \mathrm{~min}$ 


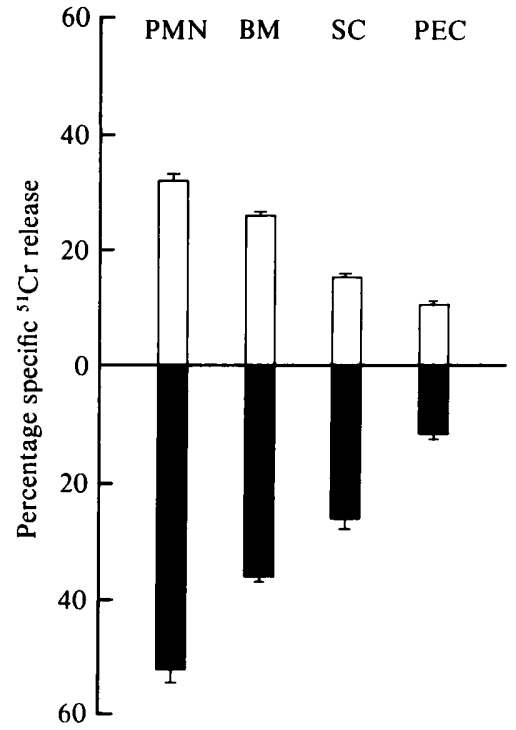

Fig. 2. Comparative killing efficiency of different murine effectors against ${ }^{51} \mathrm{Cr}$-labelled yeast-form $(\square)$ and hyphal-form ( $\boldsymbol{D}$ ) . albicans. Various types of effector cells were incubated with the radiolabelled fungi at an effector:target ratio of $10: 1$. Vertical bars represent SEM.

and reached a maximum after $4 \mathrm{~h}$. With hyphal forms (Fig. $1 \mathrm{~b}$ ) peak levels of specific ${ }^{51} \mathrm{Cr}$ release were observed after as little as $1 \mathrm{~h}$ of incubation. The specific release then decreased and reached a lower level plateau after $2-4 \mathrm{~h}$. This decrease was obviously related to the concomitant increase in the baseline control values (Fig. 1, lower panel).

\section{Effect of serum addition}

It is well documented that serum addition often increases the killing activity of effector cells against microbial targets. We therefore investigated whether the presence of serum was mandatory for the killing of C. albicans, and whether any increase in killing could be achieved by the addition of autologous as well as hyperimmune serum. All tested sera, whether heatinactivated or not, were ineffective in increasing the rate of ${ }^{51} \mathrm{Cr}$ release by SC and PMN from both yeast- and hyphal-form C. albicans (Table 2).

Comparative killing ability of different murine effector cells against yeast- and hyphal-form C. albicans

Experiments were done to compare the efficiency of different murine effectors against yeast cells or hyphae used as targets in the radiolabel release microassay described above. Those effector cells (BM, PMN) which were the most efficient at killing yeasts were also able to kill, to an even greater extent, mycelial targets (Fig. 2). Indeed, no major discrepancies were observed in the ability of any effector to attack the two different targets, in spite of what could be expected on the basis of the structural and chemical differences between the yeast and hyphal forms of the micro-organism (see Discussion).

\section{Time course of ${ }^{51} \mathrm{Cr}$ release from C. albicans cells at different stages of yeast to mycelial transition}

We also investigated the susceptibility to killing of $C$. albicans at different stages during germtube induction and hyphal formation. Yeast-form C. albicans at $0 \mathrm{~min}$ and $30 \mathrm{~min}$ (organisms which were harvested and labelled after $30 \mathrm{~min}$ of induction when no germ-tubes had emerged) displayed the same degree of susceptibility to SC and PMN, both in terms of extent and 
Table 3. Time course of ${ }^{51} \mathrm{Cr}$ release from $C$. albicans cells at different stages of yeast-mycelial transition

Germ-tube $(30 \mathrm{~min}$ ) cells were recovered $30 \mathrm{~min}$ after germ-tube induction and germ-tubes $(90 \mathrm{~min})$ were recovered $90 \mathrm{~min}$ after germ-tube induction. Hyphal cells were recovered after 240 min induction. Percentage specific ${ }^{51} \mathrm{Cr}$ release was measured at the effector : target ratio $10: 1$. Standard errors, always below $2.5 \%$, have been omitted.

\begin{tabular}{|c|c|c|c|}
\hline \multirow{2}{*}{$\begin{array}{l}\text { Target } \\
\text { cell }\end{array}$} & \multirow{2}{*}{$\begin{array}{l}\text { Time of } \\
\text { incubation } \\
\text { with effectors } \\
\text { (min) }\end{array}$} & \multicolumn{2}{|c|}{$\begin{array}{l}\text { Percentage specific } \\
{ }^{51} \mathrm{Cr} \text { release in the } \\
\text { presence of: }\end{array}$} \\
\hline & & PMN & SC \\
\hline \multirow[t]{4}{*}{ Yeast } & 30 & $14 \cdot 0$ & 1.6 \\
\hline & 60 & 16.0 & 5.68 \\
\hline & 120 & 19.7 & $8 \cdot 15$ \\
\hline & 240 & $24 \cdot 5$ & $14 \cdot 6$ \\
\hline \multirow{4}{*}{$\begin{array}{r}\text { Germ-tube } \\
(30 \mathrm{~min})\end{array}$} & 30 & $12 \cdot 2$ & 1.62 \\
\hline & 60 & $15 \cdot 1$ & 3.44 \\
\hline & 120 & $14 \cdot 5$ & 8.78 \\
\hline & 240 & $20 \cdot 7$ & $17 \cdot 6$ \\
\hline \multirow{4}{*}{$\begin{array}{r}\text { Germ-tube } \\
(90 \mathrm{~min})\end{array}$} & 30 & $37 \cdot 0$ & 17.5 \\
\hline & 60 & $29 \cdot 2$ & 15.0 \\
\hline & 120 & $20 \cdot 3$ & 14.9 \\
\hline & 240 & 21.9 & 14.9 \\
\hline \multirow[t]{4}{*}{ Hyphal } & 30 & $17 \cdot 2$ & $7 \cdot 70$ \\
\hline & 60 & $35 \cdot 1$ & $29 \cdot 2$ \\
\hline & 120 & $25 \cdot 0$ & $19 \cdot 2$ \\
\hline & 240 & $19 \cdot 6$ & $21 \cdot 1$ \\
\hline
\end{tabular}

Table 4. Correlation between ${ }^{51} \mathrm{Cr}$ release from hyphal-form C. albicans by murine PMN in vitro and decrease of pathogenicity in vivo

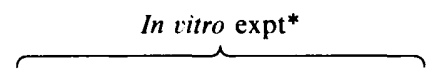

\section{Effector : target} ratio

$10: 1$

$$
5: 1
$$$$
2 \cdot 5: 1
$$

Percentage ${ }^{51} \mathrm{Cr}$ release

Group
1
2
3
4

In vivo expt ${ }^{\dagger}$

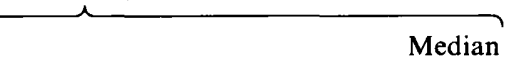

Median survival time (d)

$5 \times 10^{4}$ hyphal-form C. albicans

3

$5 \times 10^{4}$ hyphal-form C. albicans after $1 \mathrm{~h}$ incubation with murine PMN (effector:target ratio $10: 1$ )

$5 \times 10^{4}$ hyphal-form C. albicans after $1 \mathrm{~h}$ incubation with murine PMN (effector: target ratio $5: 1$ )

$5 \times 10^{4}$ hyphal-form C. albicans after $1 \mathrm{~h}$ incubation with murine PMN (effector: target ratio $2 \cdot 5: 1$ )

* The same PMN cell population was used as effector in the in vitro assay and was incubated with unlabelled hyphal-form targets to be injected in the in vivo experiment.

+ Mice immunosuppressed with cyclophosphamide were injected intravenously with $5 \times 10^{4}$ hyphal-form cells previously incubated for $1 \mathrm{~h}$ with RPMI medium (group 1) or with PMN (groups 2, 3 and 4).

$\ddagger P<0 \cdot 01$, according to the Mann-Whitney U-test.

rate of killing (Table 3 ). The most susceptible target appeared to be germ-tubes $(90 \mathrm{~min})$ (corresponding to a stage of well emerged germ-tubes), which were optimally killed within the first $30 \mathrm{~min}$ of effector plus target incubation. The hyphal form displayed its typical pattern of susceptibility, with peak levels of specific ${ }^{51} \mathrm{Cr}$ release observed after $60 \mathrm{~min}$ of incubation. 


\section{Correlation between ${ }^{51} \mathrm{Cr}$ release from hyphal-form C. albicans in vitro and decrease of pathogenic potential evaluated in vivo}

We tried to correlate ${ }^{51} \mathrm{Cr}$ release from hyphal forms with the actual killing of the microorganisms. Apart from dye exclusion tests (see above), we also did in vivo experiments in which mice immunodepressed with cyclophosphamide $\left[150 \mathrm{mg}(\mathrm{kg} \text { body } \mathrm{wt})^{-1}\right.$, given $3 \mathrm{~d}$ before the challenge] were injected intravenously with hyphal-form C. albicans previously incubated either in RPMI medium alone or with murine PMN at different effector : target ratios. The same PMN were also used as effectors in the radiolabel release microassay at the same effector : target ratios. The results show that the incubation of hyphal cells with PMN before inoculation significantly decreased the pathogenicity of $C$. albicans hyphal forms (groups 2, 3 and 4 versus group 1; Table 4), thus providing evidence that the ${ }^{51} \mathrm{Cr}$ release observed in vitro might correspond to an actual reduction in the number of live hyphal forms, as with yeast forms (Bistoni et al., 1982).

\section{DISCUSSION}

Yeast-mycelial conversion has long been claimed to play a crucial role in the pathogenicity of C. albicans (for a review see Odds, 1979). Despite these claims, however, the relative virulence of the two forms of the fungus remains to be established because both yeast and mycelial forms are found in the tissues of infected animals (Winblad, 1975; Parker et al., 1976), and experimental infections with the two forms of growth do not clearly indicate which one is really the more virulent (Odds, 1979). Very recently, Cockayne \& Odds (1984), presented evidence to suggest that hyphal forms of $C$. albicans are more susceptible to killing by human PMN effectors than yeast forms.

Since natural defence mechanisms are critical in host resistance against candidiasis both in normal and immunomodulated hosts (Rogers \& Balish, 1980; Kagaya \& Fukazawa, 1981; Bistoni et al., 1983; Baccarini et al., 1983a,b), it seemed of interest to do a rapid assay which allowed the simultaneous testing of different murine effector cell populations for their natural reactivity against both yeast and hyphal forms of $C$. albicans. Using PMN (a highly reactive population against yeast-form $C$. albicans), we found that good levels of specific ${ }^{51} \mathrm{Cr}$ release from the hyphal form were achieved at the effector:target ratios of $10: 1$ to $5: 1$.

As previously reported for yeast forms (Bistoni et al., 1982), ${ }^{51} \mathrm{Cr}$ release from hyphal forms correlated well with actual killing as shown by microscopic observation, trypan blue exclusion and in vivo challenge of cyclophosphamide-immunosuppressed mice with PMN-treated hyphal forms (see Results). Although a detailed assessment of the form-related differences in attachment, ingestion and intracellular versus extracellular killing was not within the scope of this investigation, it was observed that yeast-form cells were first phagocytosed then killed intracellularly, whereas hyphal forms were predominantly killed extracellularly, at least by murine PMN effectors. The nature and mechanism of this non-phagocytic killing are presently under investigation but it has already been suggested that human PMN are able to damage noningested pseudohyphal forms of $C$. albicans (Diamond et al., 1978). Thioglycollate-induced peritoneal murine PMN could be particularly efficient in this form of extracellular killing. Whatever the mechanism, we observed that the rate of killing of hyphal forms was comparable to, or even higher than, that of yeast forms. We also observed that the addition of serum, either autologous, heterologous or immune, and the presence of complement were not mandatory for killing of hyphal forms, extending to these latter what is widely recognized for yeast forms (Lehrer \& Cline, 1969; Yamamura et al., 1977; Diamond et al., 1978; Kagaya \& Fukazawa, 1981 ; Bistoni et al., 1982).

When the ability of different murine effectors to kill yeast and hyphal forms of $C$. albicans was analysed, the most efficient effectors were BM cells and PMN, which have already proved capable of killing yeast-form C. albicans in a variety of systems (Bistoni et al., 1982; Lehrer \& Cline, 1969), and, in some cases, of damaging pseudohyphae (Diamond et al., 1978). Lower levels of killing were displayed by SC, while PEC were almost totally inefficient. The differential killing of $C$. albicans at different stages during induction of germ-tube and hyphal formation is also of some interest. In fact, yeast and germ-tube $(30 \mathrm{~min})$ forms were relatively 
more resistant to killing by SC and PMN than elongating (germ-tube, $90 \mathrm{~min}$ ) and truly mycelial forms $(240 \mathrm{~min})$, both in terms of the amount of ${ }^{51} \mathrm{Cr}$ released and in the time of incubation required to achieve maximal killing. The reason for such a discrepancy may reside in the wellknown differences in cell wall composition and architecture of the two growth forms (Chattaway et al., 1968; Cassone et al., 1973; Braun \& Calderone, 1978; White et al., 1979), which may also account for variations in the pathogenic potential of the fungus. For PMN cells at least, the mechanism of killing could also differ between yeast and hyphal cells, with intracellular and extracellular killing making different contributions towards the various stages of morphological transition.

Another potentially important factor in the relatively greater resistance of yeast forms to killing could be their ability to form germ-tubes even when they have already been phagocytosed (Odds, 1979). This phenomenon, however, would not be decisive where effective extracellular killing of hyphal forms occurs.

Despite the well defined in vitro conditions under which our experiments were done, no definite conclusions can be drawn about the relative in vivo pathogenicity of yeast and hyphal forms of $C$. albicans. In principle, hyphal forms produced in response to GlcNAc could be significantly different from those which are formed in serum and animal tissues, as far as resistance to immune effectors is concerned. Although experiments with germ-tubes and hyphae developed in serum showed that they are killed by murine effectors, just like the ones formed in GlcNAc medium (data not shown), this is still far from an in vivo situation. However, it is of interest that, at least under one set of conditions, those murine effector cells which are capable of killing the yeast form also kill (sometimes with higher efficiency) the hyphal form. Also of - interest is the fact that susceptibility to killing apparently increases with germ-tube emergence and hyphal growth.

Finally, it should be stressed that, despite numerous differences in the nature and activity of the immune effectors and in the techniques used to assess cell killing, our findings are substantially in accord with those of Cockayne \& Odds (1984). The results of both studies seem to contradict the commonly held belief that hyphal forms of $C$. albicans are endowed with a greater invasiveness and resistance to host defences than yeast forms.

This work was supported by grants from CNR (Italy) under special project 'Controllo delle malattie infettive', contract nos. 83.00628.52 and 83.02916.52.

\section{REFERENCES}

Baccarini, M., Bistoni, F., Puccetti, P. \& Garaci, E. $(1983 a)$. Natural cell-mediated cytotoxicity against Candida albicans induced by cyclophosphamide. Nature of the in vitro cytotoxic effector. Infection and Immunity 42, 1-9.

Baccarini, M., Blasi, E., Puccetti, P. \& Bistoni, F. $(1983 b)$. Phagocytic killing of Candida albicans by different murine effector cells. Sabouraudia 21, 271286.

Bistoni, F., Baccarini, M., Blasi, E., Puccetti, P. \& MARCONI, P. (1982). A radiolabel release microassay for phagocytic killing of Candida albicans. Journal of Immunological Methods 52, 369-377.

Bistoni, F., Baccarini, M., Blasi, E., Puccetti, P., Marconi, P. \& Garaci, E. (1983). Correlation between 'in vivo' and 'in vitro' studies of modulation of resistance to experimental Candida albicans infection by cyclophosphamide in mice. Infection and Immunity 40, 46-55.

Braun, P. C. \& Calderone, R. A. (1978). Chitin synthesis in Candida albicans: comparison of yeast and hyphal forms. Journal of Bacteriology 133, 14721477.
Cassone, A., Simonetti, N. \& Strippoli, V. (1973). Ultrastructural changes in the wall during germ-tube formation from blastospores of Candida albicans. Journal of General Microbiology 77, 417-426.

Chattaway, F. W., Holmes, M. R. \& Barlow, A. J. E. (1968). Cell wall composition of the mycelial and blastospore forms of Candida albicans. Journal of General Microbiology 51, 367-376.

COCKAYNE, A. \& ODDS, F. C. (1984). Interaction of Candida albicans yeast cells, germ tubes and hyphae with human polymorphonuclear leukocytes in vitro. Journal of General Microbiology 130, 465-471.

Dabrowa, N., TAXER, S. S. \& Howard, D. (1976). Germination of Candida albicans induced by proline. Infection and Immunity 13, 830-835.

Davies, R. R. \& Denning, T. J. V. (1972). Candida albicans and the fungicidal activity of the blood. Sabouraudia 10, 301-312.

Diamond, R. D., WRzesicki, R. \& Wellington, J. (1978). Damage to pseudohyphal forms of Candida albicans by neutrophils in the absence of serum in vitro'. Journal of Clinical Investigations 61, 349-359. 
Gould, T. J. L., Schotte, C. \& van Fourth, R. (1975). Identification and characterization of the monoblast in mononuclear phagocyte colonies grown 'in vitro'. Journal of Experimental Medicine 142, 1180-1199.

Kagaya, K. \& Fukazawa, Y. (1981). Murine defense mechanisms against Candida albicans infection. II. Opsonization, phagocytosis and intracellular killing of C. albicans. Microbiology and Immunology 25, 807818.

Lehrer, R. I. \& Cline, M. J. (1969). Interaction of Candida albicans with human leukocytes and serum. Journal of Bacteriology 98, 998-1004.

LODDER, J. (1970). The Yeasts: A Taxonomic Study, p. 914. Amsterdam, London: North Holland Publishing Company.

Marconi, P., Bistoni, F., Boncio, L., Bersiani, A., Bravi, P. \& Pitzurra, M. (1976). Utilizzazione di una soluzione salino ipertonica di cloruro di potassio (3M KCL) per l'estrazione di antigeni solubili da Candida albicans. Annali sclavo 18, 61-66.

MatTIA, E. \& CAsSONE, A. (1979). Inducibility of germtube formation in Candida albicans at different phases of yeast growth. Journal of General Micrabiology 113, 439-442.

Mattia, E., Carruba, C., Anglolella, L. \& Cassone, A. (1982). Induction of germ-tube formation by $N$ acetyl-D-glucosamine in Candida albicans: uptake of inducer and germinative response. Journal of Bacteriology 152, 555-562.

ODDs, F. C. (1979). Candida and Candidosis. Leicester: Leicester University Press.
Parker, J. C., McCloskey, J. J. \& Knauer, K. A. (1976). Pathobiologic features of human candidiasis. A common deep mycosis of the brain, heart and kidney in the altered host. American Journal of Clinical Pathology 65, 991-999.

Rogers, T. S. \& BALISH, E. (1980). Immunity to Candida albicans. Microbiology Review's 44, 660-682. Saltarelli, C. G., Gentile, K. A. \& Mancuso, S. C. (1975). Lethality of Candida strains as influenced by the host. Canadian Journal of Microbiology 21, 648653.

ShePherd, M. G., Chiew, Y. Y., Ram, S. P. \& Sullivan, P. A. (1980). Germ-tube induction in Candida albicans. Canadian Journal of Microbiology 26, 21-26.

Simonetti, N., Strippoli, V. \& Cassone, A. (1974). Yeast-mycelial conversion induced by $N$-acetyl-Dglucosamine in Candida albicans. Nature, London 250, 344-346.

White, L. O., Gibb, E., Newham, H. C., Richardson, M. D. \& Warren, R. C. (1979). Comparison of the growth of virulent and attenuated strains of Candida albicans in the kidneys of normal and cortisonetreated mice by chitin assay. Mycopathologia 67, 173-176.

Winblad, B. (1975). Experimental renal candidiasis in mice and guinea pigs. Acta pathologica et microbiologica scandinatica 83, 400-407.

Yamamura, M., Boler, J. \& Valdimarsson, H. (1977). Phagocytosis measured as inhibition of uridine uptake by Candida albicans. Journal of Immunological Methods 14, 19-24. 